WWW.jmscr.igmpublication.org

Impact Factor 5.84

Index Copernicus Value: 83.27

ISSN (e)-2347-176x ISSN (p) 2455-0450

crossref DOI: https://dx.doi.org/10.18535/jmscr/v5i6.39

Journal Of Medical Science And Clinical Research

\title{
A Study of Serum Calcium Levels during First Week of Life in Normal Term Neonates
}

\author{
Authors \\ Dr Mohammad Asif ${ }^{1}$, Dr Suresh Goyal ${ }^{2}$, Dr Rameshwar Ninama ${ }^{3}$, \\ Dr Savita Shekhawat ${ }^{3}$ \\ Department of Paediatrics RNT Medical College Udaipur \\ Email: rntianasif@gmail.com, Mobileno:09414263091 \&09785056044 \\ Corresponding Author \\ Dr Mohammad Asif \\ C/O Bandhni Emporium Hathipole Circle Udaipur Rajasthan- Pin 313001
}

\begin{abstract}
ABSTACT
Introduction: Transition from foetal to neonatal life is associated with major changes in fluid and electrolyte levels due to homeostatic control.

Aims \& Objective: This study was planned to study changes of serum Calcium in cord blood and during first week of life.

Material \& Method:100 Normal term neonates with gestational age $>37$ weeks \& birth weight $>2100$ gm were included in the study. Serum Calcium was studied in cord blood, 24 hrs, 48 hrs, 7th day of life and mean, range \& standard deviation were Calculated.

Results: The range of serum calcium in cord blood, at $24 \mathrm{hrs}, 48 \mathrm{hrs} \& 7$ days in our study was 7.9-13.2 $\mathrm{mg} / \mathrm{dl}, 7.6-11.7 \mathrm{mg} / \mathrm{dl}, 7.0-11.1 \mathrm{mg} / \mathrm{dl} \&$ 7.4-10.9 $\mathrm{mg} / \mathrm{dl}$ respectively The levels of serum calcium found in our study showed a very wide range. In this study the mean \pm SD serum calcium in cord blood, at 24 hrs, 48 hrs \& 7 days was $9.9 \pm 0.94 \mathrm{mg} / \mathrm{dl}, 9.1 \pm 0.89 \mathrm{mg} / \mathrm{dl}, 8.9 \pm 0.89 \mathrm{mg} / \mathrm{dl} \& 9.2 \pm 0.77 \mathrm{mg} / \mathrm{dl}$ respectively The trend of serum calcium in our study showed a decreasing trend till 48 hrs with a rise at 7 days but it remains to a level below cord calcium values.

Summary: This study showed very wide range of serum Calcium levels that seems to be abnormally high or low in healthy term neonate in cord blood and during first week of life but these were actually normal for that neonatal period depending upon gestational and post natal age. Serum Calcium levels fall till 48 hours of life to rise again till 7 day of life in healthy term neonate which shows that serum calcium undergo a physiological nadir at around 48 hrs of life.

Conclusion: The normal values of Serum Calcium in neonates are different from other age groups and it varies with postnatal age and gestational age so same refrence range of electrolytes should not be used in all neonates instead a refrence range derived from large neonatal datasets of varied gestational and postnatal age should be used, such as those presented here for healthy term neonates.

Keywords: Serum Calcium, term neonates, cord blood, foetal transition, homeostasis.
\end{abstract}




\section{Introduction}

The importance and difficulty of assessment and management of fluid and electrolyte status during the first week of life in the neonate can be as great as ever encountered in medicine. One reason is that the transition from foetal to neonatal life is associated with major changes in water and electrolyte homeostatic control. Before birth, the foetus has a constant supply of water and electrolytes from the mother across the placenta; foetal water and electrolyte homeostasis is largely a function of placental and maternal homeostatic mechanisms that is reflected in cord blood. ${ }^{2}$

After birth neonate must rapidly assume responsibility for its own fluid and electrolyte homeostasis in an environment in which fluid and electrolyte availability and losses fluctuate much more widely than in utero. Moreover, for reasons that are not understood, the transition from foetal to neonatal life is associated with what have come to be accepted as normal changes in fluid and electrolyte balance. These small changes in fluid and electrolyte quantity represent large proportionate changes in neonate because of neonate's small size. ${ }^{1,2}$

The reference ranges of serum Calcium is usually established on the basis of the statistical distribution of results within a sample of population. ${ }^{1}$ The studies done to find normal distribution levels of these electrolytes till date are very limited.

The normal reference range of serum electrolytes quoted in various textbooks have a very wide range \& seems to be abnormal ${ }^{7,8,9,10,11}$. The normal reference range of Serum Calcium in a term neonate quoted in Rennie textbook of Neonatology \& Nelson textbook of pediatrics is as 13, 14: Serum Ca+: 8.56-9.40 mg/dl.

The laboratory value obtained at extreme of these ranges or outside these ranges seems to be abnormal and pathological and may need to be treated accordingly. In neonatal period first week of life is associated with fluid and electrolyte changes in an attempt to maintain homeostasis after transition from foetal to neonatal period. These abnormal electrolyte levels are common during this period \& are a part of that physiological process of transition from foetal to neonatal period. These abnormal serum Calcium levels do not have any pathophysiological or clinical effects in neonate and are considered to be normal for that period ${ }^{2}$.

This study was planned to study these normal physiological changes of serum Calcium during first week of life which will help in better diagnosis and management of fluid and electrolyte disorders during first week of life. This study will help to establish that these extreme and abnormal values of serum Calcium do not have any clinicopathological effects on neonate and are normal for that neonatal period and will also establish a normal reference range of Serum Calcium during first week of life.

\section{Material and Methods}

This study was conducted at in Department of Pediatrics of Medical College. The study was carried out during the period of June 2009 to November 2009. A total of 100 term neonates delivered at Mahila Chiktsalaya were included in the study. The cases that fulfilled the inclusion and exclusion criteria during work up were randomly selected to be included in the study.

Work up done for the cases to be included in the study was:

An informed written consent to participate in the study from parents was taken

- Detailed antenatal, natal, postnatal history.

- Clinical examination of neonate at birth, $24 \mathrm{hrs}, 48 \mathrm{hrs} \& 7$ days of life.

- Assessment of gestational age using New Ballard Scoring System ${ }^{17}$.

- Investigations :serum Calcium in cord blood, at $24 \mathrm{hrs}, 48 \mathrm{hrs}$ and 7days of life. (subject to fulfillment of inclusion and exclusion criteria)

The cases that were included in the study were having following inclusion and exclusion criteria. 


\section{Inclusion Criteria}

- Normal healthy term neonates delivered at Mahila Chiktsalaya vaginally or by caesarean section with gestational age $\geq 37$ weeks and birth weight $>2100 \mathrm{gm}(\geq 10$ th percentile for term neonates) were included in the study.

\section{Exclusion criteria}

- Gestational age <37 weeks.

- Birth weight $<10^{\text {th }}$ percentile of that gestational age: any evidence of IUGR.

- Neonates with history of birth asphyxia (Apgar score $<5$ at $5 \mathrm{~min}$ ).

- Meconium aspiration syndrome.

- Clinical signs and symptoms of neonatal sepsis or any other neonatal illness.

- Presence of maternal risk factors like

$>$ Use of oxytocin during labour.

$>$ Use of hypotonic fluid given to mother during labour.

$>$ History of PIH in mother and taken antihypertensive medications like ACE inhibitors.

$>$ Prolonged and difficult labour/ instrumentation.

$>$ Foul smelling liquor or Meconium stained liquor.

D Evidence of chorioamnionitis or PROM.

$>$ Poorly controlled maternal diabetes mellitus.

$>$ Any chronic illness in mother.

$>$ History of oligohydramnios or polyhydramnios.

- Any evidence of any gross congenital or chromosomal malformation.

- Evidence of antenatal steroids given to mother.

\section{Methods}

As per Performa, detailed antenatal, natal \& post natal history was taken, gestational age estimation was done according to New Ballard Scoring System as below \& clinical examination was performed. $^{17}$

\section{Investigations}

The estimation of serum Calcium was done by collecting cord blood and venous blood at $24 \mathrm{hrs,}$ $48 \mathrm{hrs}$ and 7 days of life using standard methods used in the Institute and was analyzed at Path Labs in the hospital. The samples were collected during the hospital stay at birth, $24 \mathrm{hrs} \& 48 \mathrm{hrs} \&$ 7 days of life. Cases that were discharged before 7 days of life were called up in outpatient department for sample collection and attended personally. The quantitative estimation of serum Calcium was done on automated analyzer -Roche Diagnostics.

\section{Specimen collection}

Collection of cord blood: using the Bag method $^{12}$

Once the cord is clamped and cut, the maternal end of cord was elevated and by using the force of gravity to drain the blood from the cord and placenta into plain \& EDTA vials.

\section{Collection of venous blood}

The venous blood was drawn under strict aseptic precaution from fresh venipunture site using 24 gauge and 22 gauge needle.

\section{Statistical calculations}

- Mean: Sum of all observations / Total no. of observations.

- Standard deviation: Square root of (any observation - mean value $\div$ total no. of observation).

- Range: It is the difference between maximum value and minimum value of the observations, and is expressed using both max and min values.

- Median: It is the middle value of all data set after arranging from min to maximum.

\section{Results}

The present study was conducted at Department of Pediatrics, Medical College, during the period of October 2009 to November 2009

Out of the 100 cases $55(55 \%)$ cases were male $45(45 \%)$ cases were females in the study.

Out of total 100 cases, $48(48 \%)$ cases were of 38 weeks of gestation, $36(36 \%)$ cases were of 40 
weeks gestation and 16(16\%) were of 42 weeks of gestational age. The mean, median and standard deviation of gestational age of neonates in the study were 39.4 weeks, 40 weeks and 1.3 weeks, respectively.

In this study, highest number of neonates (52\%) had birth weight in the range of 2500-2999 grams and the least number of neonates $(6 \%)$ had a birth weight $\geq 3500$ grams. The mean, median and standard deviation of birth weight in this study was 2808 grams, 2780 grams and 306 grams, respectively. The range of birth weight in this study was 2210 to 3900 grams.

In this study out of the 100 neonates $31(31 \%)$ were delivered by cesarean section and 69(69\%) were spontaneously normal delivered

The mean, median and standard deviation of serum calcium in cord blood at birth in this study were $9.9 \mathrm{mg} / \mathrm{dl}, 9.8 \mathrm{mg} / \mathrm{dl}$ and $0.94 \mathrm{mg} / \mathrm{dl}$ respectively. The range of serum calcium in cord blood was $7.9-13.2 \mathrm{mg} / \mathrm{dl}$

The mean, median and standard deviation of serum calcium at $24 \mathrm{hrs}$ of life in this study were $9.1 \mathrm{mg} / \mathrm{dl}, 9.1 \mathrm{mg} / \mathrm{dl}$ and $0.89 \mathrm{mg} / \mathrm{dl}$ respectively. The range of serum calcium at 24 hrs was 7.6$11.7 \mathrm{mg} / \mathrm{dl}$.

The mean, median and standard deviation of serum calcium at $48 \mathrm{hrs}$ of life in this study were $8.9 \mathrm{mg} / \mathrm{dl}, 8.7 \mathrm{mg} / \mathrm{dl}$ and $0.89 \mathrm{mg} / \mathrm{dl}$ respectively. The range of serum calcium at $48 \mathrm{hrs}$ was $7.0-11.1$ $\mathrm{mg} / \mathrm{dl}$.

The mean, median and standard deviation of serum calcium at 7 days of life in this study were $9.2 \mathrm{mg} / \mathrm{dl}, 9.1 \mathrm{mg} / \mathrm{dl}$, and $0.77 \mathrm{mg} / \mathrm{dl}$ respectively. The range of serum calcium at 7 days of life was $7.4-10.9 \mathrm{mg} / \mathrm{dl}$.

\begin{tabular}{|l|c|c|c|}
\hline Time of sample & $\begin{array}{c}\text { Mean Serum } \\
\text { Calcium }(\mathrm{mg} / \mathrm{dl})\end{array}$ & $\begin{array}{c}\text { Standard } \\
\text { deviation }(\mathrm{mg} / \mathrm{dl})\end{array}$ & Range $(\mathrm{mg} / \mathrm{dl})$ \\
\hline Cord Blood at Birth & 9.9 & 0.94 & $7.9-13.2$ \\
\hline 24 Hr of Life & 9.1 & 0.89 & $7.6-11.7$ \\
\hline 48 Hr of Life & 8.9 & 0.89 & $7.0-11.1$ \\
\hline 7 Days of Life & 9.2 & 0.77 & $7.4-10.9$ \\
\hline
\end{tabular}

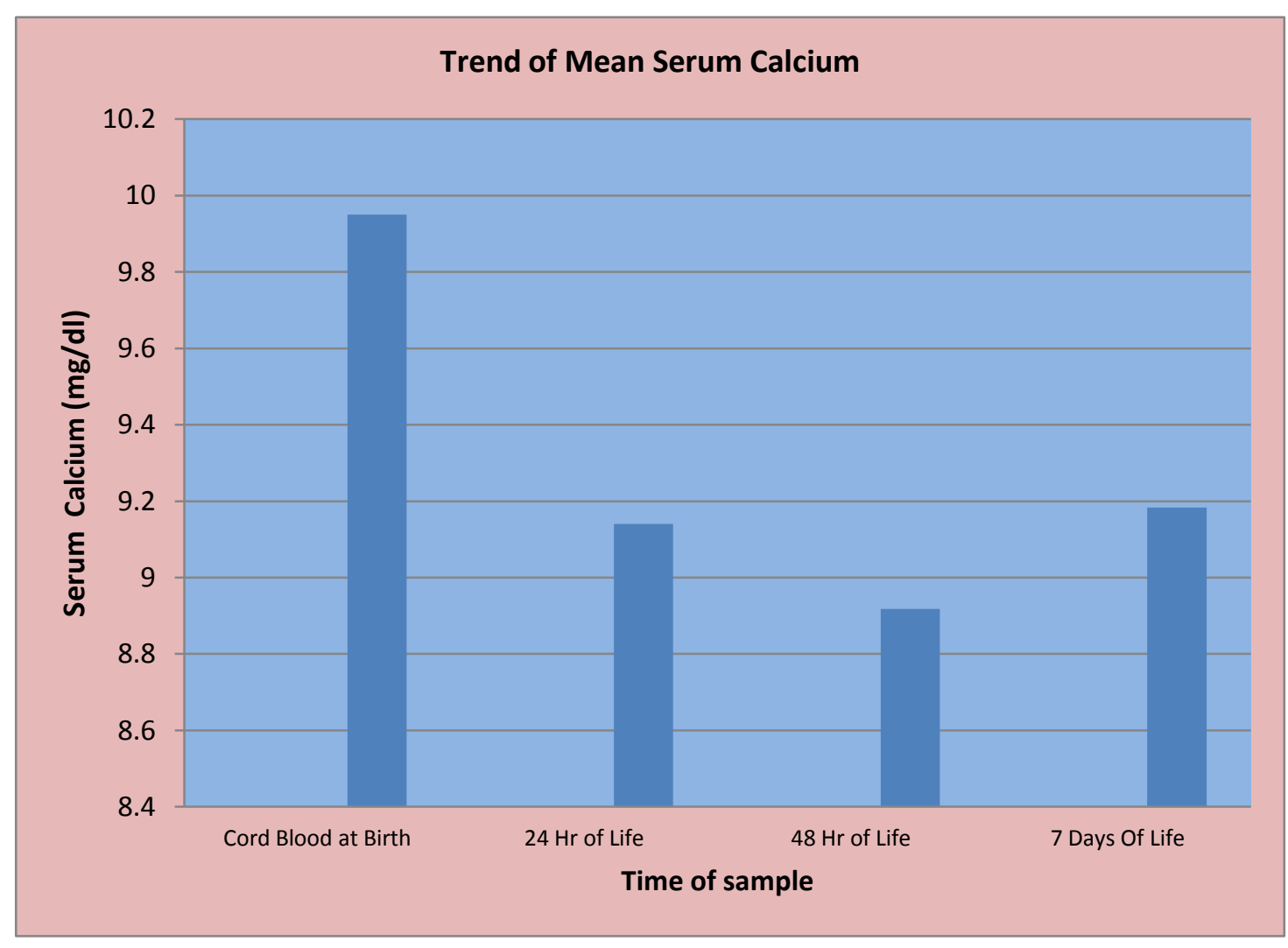




\section{Discussion}

In this study the mean $\pm \mathrm{SD}$ serum calcium in cord blood, at $24 \mathrm{hrs}, 48 \mathrm{hrs} \& 7$ days was $9.9 \pm$ $0.94 \mathrm{mg} / \mathrm{dl}, 9.1 \pm 0.89 \mathrm{mg} / \mathrm{dl}, 8.9 \pm 0.89 \mathrm{mg} / \mathrm{dl} \&$ $9.2 \pm 0.77 \mathrm{mg} / \mathrm{dl}$ respectively, the corresponding figures in other studies were as follows: in study done by P. T

Acharya and W. W Payne ${ }^{1}$ (1965) the mean serum calcium in cord blood, at $24 \mathrm{hrs} \& 48 \mathrm{hrs}$ was $9.34 \mathrm{mg} / \mathrm{dl}, \quad 7.7 \mathrm{mg} / \mathrm{dl} \quad \& \quad 7.94 \mathrm{mg} / \mathrm{dl}$ respectively. In study of preterm infants by Jack L. Thomas \& Thomas E. Reichelderfer ${ }^{5}$ (1967) mean \pm SD serum calcium was $9.2 \pm 1.1 \mathrm{mg} / \mathrm{dl}$ at 7 days of life. In study of plasma calcium and magnesium in newborn babies done by Harvey D. R., Cooper L. V. and J. F. Stevens ${ }^{2}$ in 1970, the mean \pm SD serum calcium in breast fed babies on day2, day3 \& day7 were $7.5 \mathrm{mg} / \mathrm{dl}, 9.3 \mathrm{mg} / \mathrm{dl} \&$ $8.9 \mathrm{mg} / \mathrm{dl}$. In study by Louis David and Constantine S. Anast ${ }^{3}$ in 1974 on calcium metabolism in newborn infants the mean \pm SD serum calcium in cord blood, 24-48 hrs, 96-158hrs of life was $10.84 \pm 0.66 \mathrm{mg} / \mathrm{dl}, 9.46 \pm 0.67 \mathrm{mg} / \mathrm{dl}$ $\& 9.97 \pm 0.88 \mathrm{mg} / \mathrm{dl}$ respectively. The trend of serum calcium in our study shows a decreasing trend till $48 \mathrm{hrs}$ with a rise at 7 days but it remains to a level below cord calcium values. This shows that serum calcium undergo a physiological nadir at around $48 \mathrm{hrs}$ of life. This nadir may be related to the delayed response of parathyroid \& calcitonin hormones in newborn or some poorly understood condition. This trend of serum calcium obtained in our study was not similar to that in study by P. T Acharya and W. W Payne ${ }^{1}$ (1965) in which there was nadir at 24 hrs of life. In study by Harvey D. R., Cooper L. V. and J. F. Stevens ${ }^{2}$ in 1970 there was nadir of serum calcium at day 2 of life. In study by Louis David and Constantine S.
Anast $^{3}$ in 1974 on calcium metabolism in newborn infants there was physiological nadir of serum calcium during $24-48 \mathrm{hrs}$ of life to rise again till 96-158 hrs of life.

The range of serum calcium in cord blood, at 24 hrs, 48 hrs \& 7 days in our study was $7.9-13.2$ $\mathrm{mg} / \mathrm{dl}, 7.6-11.7 \mathrm{mg} / \mathrm{dl}, 7.0-11.1 \mathrm{mg} / \mathrm{dl} \& 7.4-10.9$ $\mathrm{mg} / \mathrm{dl}$ respectively whereas in study done by $\mathrm{P} . \mathrm{T}$ Acharya and W. W Payne ${ }^{1}$ (1965) the range of serum calcium in cord blood, at $24 \mathrm{hrs} \& 48 \mathrm{hrs}$ was $8.2-11.1 \mathrm{mg} / \mathrm{dl}, 6.2-9.0 \mathrm{mg} / \mathrm{dl} \& 5.9-9.7$ $\mathrm{mg} / \mathrm{dl}$ respectively. In study done by Jack L Thomas \& Thomas E. reichelderfer ${ }^{5}$ (1967) the range of serum calcium at 7 days of life was $6.1-$ $11.6 \mathrm{mg} / \mathrm{dl}$. In study of plasma calcium and magnesium in newborn babies done by Harvey D. R. , Cooper L. V. and J. F. Stevens ${ }^{2}$ (1970), the range of serum calcium in breast fed babies on day2, day3 \& day7 were $5.2-9.8 \mathrm{mg} / \mathrm{dl}, 7.2-$ $11.2 \mathrm{mg} / \mathrm{dl} \& 6.8-11.4 \mathrm{mg} / \mathrm{dl}$. The levels of serum calcium found in our study showed a very wide range as found in study by Acharya and W.W Payne ${ }^{1}$ (1965), Jack L Thomas \& Thomas E. Reic. Helderfer ${ }^{5}$ (1967) \& Harvey D. R., Cooper L. V. and J. F. Stevens ${ }^{2}$ (1970).

\section{Summary}

The major findings of the study were following:

1. Out of the 100 healthy full term neonates, Male to female ratio in the study was 1.22:1(11:9). The mean birth weight in this study was $2808 \pm 306$ grams and maximum number of neonates $(52 \%)$ had birth weight in the range of 2500-2999 grams.

2. The mean, standard deviation \& range of serum Calcium levels obtained in our study were as under:

\begin{tabular}{|c|c|c|c|c|}
\hline Serum Electrolyte & Cord Blood at Birth & 24 Hrs Of Life & 48 Hrs Of Life & 7 Days Of Life \\
\hline & Mean \pm SD (Range) & $\begin{array}{c}\text { Mean } \pm \text { SD } \\
\text { (Range) }\end{array}$ & $\begin{array}{c}\text { Mean } \pm \text { SD } \\
\text { (Range) }\end{array}$ & $\begin{array}{c}\text { Mean } \pm \text { SD } \\
\text { (Range) }\end{array}$ \\
\hline $\begin{array}{l}\text { Serum Calcium } \\
(\mathrm{mg} / \mathrm{dl})\end{array}$ & $\begin{array}{c}9.9 \pm 0.94 \\
(7.9-13.2)\end{array}$ & $\begin{array}{c}9.1 \pm 0.89 \\
(7.6-11.7)\end{array}$ & $\begin{array}{c}8.9 \pm 0.89 \\
(7.0-11.1)\end{array}$ & $\begin{array}{c}9.2 \pm 0.77 \\
(7.4-10.9)\end{array}$ \\
\hline
\end{tabular}


3. The various serum Calcium levels obtained in our study varied a lot from cord blood to 7 days of life as given in table and \& showed a very wide range that seems to be abnormally high /low, but these values are normal for that neonatal period depending upon the gestational and postnatal age.

4. The study shows that normal values serum Calcium in neonates are different from other age groups and it varies with postnatal age and gestational age so same reference range electrolytes should not be used in all neonates instead a reference range should be used depending upon postnatal age in both term and preterm neonates.

\section{Conclusions}

The normal serum Calcium values in healthy term neonates observed in this study showed a very wide range \& undergo a physiological nadir at around $48 \mathrm{hrs}$ of life, the values observed in that wide range of serum calcium seems to be abnormal but are actually normal for that neonatal period depending upon the postnatal age. Recognizing that a serum Calcium element is abnormally high or low can influence many clinical decisions in our day to day practice but unfortunately the reference ranges for the various electrolytes during the neonatal period are not simple, but change considerably with advancing gestational and postnatal age. Results of serum Calcium in neonates must be interpreted according to data for baby's gestational and postnatal age. If this is not done, results may be misinterpreted and diagnosis of many conditions like infection, dyselectrolytemias \& others may be missed and delayed. This cannot be accomplished using the normal ranges established in healthy adults or single group of neonates, but rather using reference ranges derived from large neonatal datasets of varied gestational and postnatal age, such as those presented here for term neonates.

\section{Recommendations}

1. Serum Calcium results for newborn must be interpreted according to data for baby's gestational and postnatal age.

2. The dataset result observed in our study should be used as a reference value for serum Calcium in full term neonates.

3. Similar studies to find out reference values of these parameters should be done in preterm and small for gestational age neonates.

\section{Bibliography}

1. Acharya PT and Payne WW. Blood chemistry of normal full term infants in first $48 \mathrm{hrs}$ of life. Arch Dis Child. 1965; 40: 430-435.

2. D. R. Harvey, Lesley V. Cooper, and J. F. Stevens. Plasma Calcium and Magnesium in Newborn Babies. Arch Dis Child. 1970 Aug; 45(242): 506-509.

3. Louis David, Constantine S. Anast. Calcium Metabolism In Newborn Infants The Interrelationship Of Parathyroid Function And Calcium, Magnesium, And Phosphorus Metabolism In Normal, "Sick," And Hypocalcemic Newborns.J Clin Invest. 1974 Aug; 54(2): 287-296.

4. Aggarwal, R., Upadhyay, M., Deorari, A.K. et al.Hypocalcemia in neonates. Indian J Pediatr (2001) 68: 973

5. Thomas JL, Reicheldelfer TE. Premature infants: Analysis of serum during the first seven weeks. Clinical Chemistry. 1968 Mar;14(3): 272-280. Websearch: clinchem.aaccjnls.org/content/14/3/272

6. Lorenz JM. Assessing fluid and electrolyte status in the Neonate. Clinical Chemistry. 1997; 43: 205-210.

7. David E. Hertz. Care of the neonate, a handbook for primary care, 1st edi.: Lippincott Williams \& Wilkins; 2005: 186.

8. Taeusch HW, Ballard RA, Gleason CA, Avery ME. Avery's Diseases of The Neon- 
ate, 6th edition: Elsevier publications; 2005: 380 .

9. Crocetti M, Barone MA, Oski FA. Oski's Essential Pediatrics, 2nd edition: Lippincott Williams \& Wilkins; 2005: 507.

10. Cloherty JP, Eichenwald EC, Stark AR. Manual of neonatal care, $6^{\text {th }}$ edition: Lippincott Williams \& Wilkins; 2008: 53.

11. Tietz NW (ed), Clinical guide to laboratory tests, 3rd ed. Saunders, Philadelphia, PA: 1995: 258.

12. Emedicine article: Understanding the Cord Blood Collection Procedure, URL: www.givingbirthnaturally.com/cordblood-collection.html; 2005-2006.

13. Kliegman RM, Jenson HB, Behrman RE, Stanton BF. Nelson textbook of pediatrics, $18^{\text {th }}$ edition: Saunders Elsevier publications; 2008: 2943-2949.

14. Rennie JM, Roberton NRC. Textbook of neonatology, 3rd edition: Churchill Livingstone; 1999: 1399-412.

15. Kasper, Braunwald, Fauci, Hauser, Longo, Jameson. Harrison's principles of internal medicine, 16thedition: McGraw hill; 2005: A1 - A9.

16. Oski FA, Naiman JL. Hematological problems in neonate, 3rd edition. W B Saunders, New York: 1999: 358-360.

17. Ballard JL, Khoury JC, Wegid K, Wang L, Eilers-walsman BL, Lipp R. New Ballard score, expanded to include extremely premature infants. J Pediatr 1991; 119: 417-423.

18. Singh M. Care of the neonate, 6th edition. New Delhi: Sagar publications; 2006: 473-478.

19. Ozyurek E, Cetintas S, Ceylan T, Ogus E, Haberal A, Gurakan B, Ozbek N. Complete blood parameters for healthy, small for gestational age, full term neonates. Clin. Lab. Haem. 2006; 28: 97-104. 